\title{
Animal Superstitions.
}

\section{N. W. Thomas}

To cite this article: N. W. Thomas (1901) Animal Superstitions., Folklore, 12:2, 189-194, DOI: 10.1080/0015587X.1901.9719624

To link to this article: http://dx.doi.org/10.1080/0015587X.1901.9719624

$$
\text { 曲 Published online: } 06 \text { Feb } 2012 .
$$

5 Submit your article to this journal $₫$

Џll Article views: 4

Q View related articles ¿ 
drinking; another places some fine-shredded grass over the mouth of his bottle and draws the wine through that; another takes a part of a plantain leaf, makes a channel down the middle, puts one end into his mouth, and pours the wine out of his cup on to the top end of the leaf, from whence it runs down the groove into his mouth. All these various modes of drinking are rigidly followed out of regard to the strictest injunctions of some medicine-man, who has told them that in order to prevent the return of a sickness from which they have suffered or to escape some disease they must drink wine in such and such a manner or not at all.

When a man is "on the booze," he sticks a leaf in his hair to show it, and then no notice is taken of any stupid or insulting remark he may make, or any business transactions he may enter upon:

JOHN H. WEEKS,

\section{Animal Superstitions.}

I. From Symi, Asia Minor. (Ante, p. I29.).

[The following are a selection from the notes collected for me by Mr. Demosthenes Chaviaras, and translated by Mr. W. R. Paton.]

r. The sponge-fishers think it an evil omen if they see an octopus at the first place they touch at on their way to their fishing ; they refrain from catching it.

Children's clothes on which a cat kittens are thrown away, as are those over which a bitch that has just littered passes.

When they hear the owl's cry they think it a good omen;

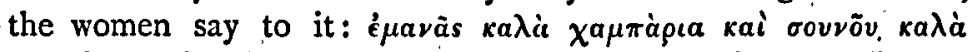



Children who catch an owl hold it by the beak and say these verses :

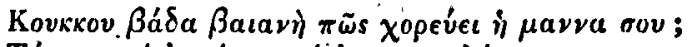

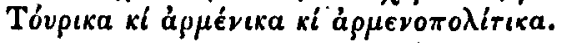

" Palm-Sunday owl, how does your mother dance?

Turkish and Armenian, Constantinople-Armenian."

And then the owl shuts its eyes and goes round like a top. 
When the crow caws it is considered a bad omen, and they say

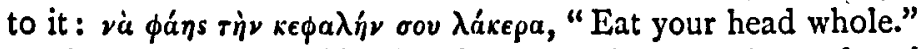

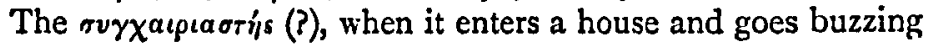
round, is looked upon as a good omen; the person round whom it flies will have good news.

The grasshopper is considered lucky; they do not kill it.

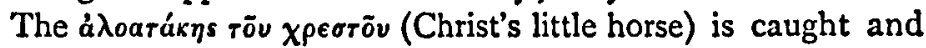
put on the palm of the left hand and the following verse said:

"If you are Christ's, stay ;

If you are the devil's, away !"

It is lucky if it remains, and vice vers $\hat{a}$.

[The creature-a kind of large grasshopper-is called in Calymnos "The Virgin's little horse"; the children when they find it say the Paternoster; if it flies away it is unlucky.-W. R. P.]

Moths and butterflies which come into the house are looked upon as lucky and are not hurt. [In Calymnos the hummingbird hawk-moth is regarded as presaging good tidings. It is

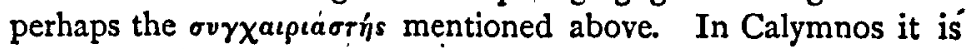

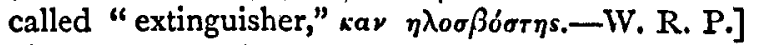

The "little bird of the house" (cricket), which usually lives near the hearth, is considered lucky when it chirps at night.

Swallows bring luck, and are respected.

Pigeons bring ill-luck and dearth; any one who eats nothing but pigeons for a fortnight will die. [Pigeons are also unlucky in Calymnos.-W. R. P.]

When a hen crows like a cock it is an omen of death; its head must be cut off with a chopper on the threshold $\dot{a} v \omega \pi i \sigma \omega$, i.e. striking it on the upper part of the neck. The fowl is eaten.

The howling of a dog is a death-omen.

When the ă $\pi \lambda_{\imath a}$ (migratory birds) pair in autumn, girls say to them :

$$
\begin{aligned}
& \text { ă } \pi \lambda_{\iota r \Omega} \mu o v \kappa a+a ́ \pi \lambda \iota \alpha \mu o v
\end{aligned}
$$

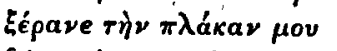

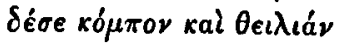

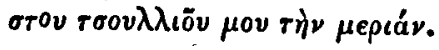

$$
\begin{aligned}
& \text { "My aplia, my kataplia, } \\
& \text { Dry my washing-stone, } \\
& \text { Tie a knot and an end knot, } \\
& \text {.In my braid of hair.". }
\end{aligned}
$$


The seal is regarded as unclean.

The öфıs, a large snake which lives near houses, was formerly looked on [as in Lesbos, W.R.P.] as the guardian of the house. It is not killed nor persecuted much, as other snakes are.

The colour of an animal seen in a dream decides whether the omen is good or bad. Black dogs or pigs seen about midnight or before cockcrow are regarded as demons or vampires; any one who sees them leaves his boots outside the tbreshold till dawn to prevent the ghosts entering the house. (The $\chi^{i \lambda \iota a \nu \tau p ı \sigma \sigma a, ~}$ a terrible apparition, was believed to traverse the town after midnight, howling savagely and accompanied by a number of pigs grunting loudly. She disappeared, like other ghosts, at cockcrow).


A man was once unjustly pursued and hid himself in a cellar; over the door a spider spun its web and saved the man.

2. To protect children from the evil eye, they hang on them the largest claw of the crab, known as $\zeta e p \beta$ òs or left.

The flesh of the tortoise and blood of the turtle give strength.

A little bone of a bat brings luck.

When a man suffers from night-blindness they say he has

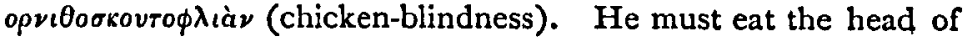
a black she-goat roasted and wash his eyes in the morning in the chickens' water-dish.

Those suffering from stone drink the stone from the gallbladder of an ox.

Those who have a wound let a dog lick it.

Those who suffer from heart-disease should eat the heart of a live pigeon.

They pound the frog in a mortar in spring, and apply it to

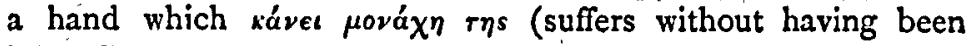
injured).

The fat of a kind of vulture and of the $\mu a x p \eta \nu^{\circ} \rho v \theta a$ is used against theumatism and colds.

The hair of the dog which has bitten a man is used to cure the bite. The hair must be removed together with a portion of the skin ; the dog cures the wound so caused by licking it. Therefore they say ironically to some one who has been ill-used by a bad man, "Cut a hair off him."

To cure a person in danger of being choked by a bone they 
hold the muzzle of a puppy not yet weaned to his mouth, and its breath helps him to swallow it. For a fish-bone they use a cat. [Also in Cos and Calymnos.-W. R. P.]

With the prickle on the back of the $\delta$ párats a (a sea-fish) they prick those suffering from toothache.

To cure a bruise, a person is put naked in a warm sheepskin.

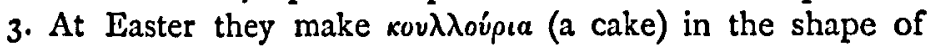
snakes ; in his mouth they put a red egg and peppercorns or cloves for the eyes.

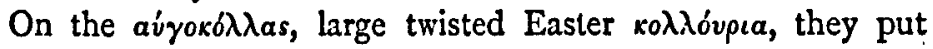
little birds made of the same dough.

4. After the funeral salt fish, bread, and wine are served to the grave-diggers; meat was formerly forbidden at the paxapia (the ancient $\pi \varepsilon p(\delta \varepsilon(\pi \nu a)$, the feast given to the relations and friends of the deceased.

5. Skulls of animals are put in the garden as scarecrows. The horns of stags or oxen are sometimes seen over the doors of houses.

\section{From Aidin, Turkey. Collected by Mr. J. Kletropoulos.}

The vulture (kartal) is not killed by Turks; the swallow, crane, large snake are also respected; so is the kaplan, or panther of West Asia Minor. It is regarded as the king of beasts; whoever kills one is imprisoned for twenty-four hours and then rewarded.

The camel is only killed and eaten on solemn occasions in Asia Minor.

The partridge is killed because it once betrayed the prophet; its legs are red because they were dipped in the blood of HassanHusein.

The pig is not called tomīz, but hinzir, "demon." Greeks


name.

The dog is often called kelp (scurfy) instead of kiotek, its proper name.

[At weddings in Aidin a pigeon is eaten by the bride and bridegroom.-W. R. P.] 
III. From Sieradz, Poland. Collected by M. I. de Piatkowska .

A goat is kept for luck. A wolf, crow, pigeon, or magpie in he house bring ill-luck.

A stork seen for the first time in flight is lucky, on the ground unlucky.

There will be a good millet year if many cockchafers are seen.

Earth taken from the ground on which wild geese have rested, and put under a tame goose when it is sitting, will ensure a good brood.

When you see the swallow for the first time in spring, you must sit down; this prevents sore feet in summer.

The first butterfly should be caught to ensure riches; you should turn your money when you hear the cuckoo, the frog, or the stork for the first time.

The swallow, nightingale, lark, stork, and owl are not killed, nor their nests touched. Bees and ants are also spared, and the word used for "die" is the same for them as for human beings. The spider is not killed. Sparrows are killed with whips.

At Christmas and during the Carnival, young men disguise themselves as animals-bear, horse, or monkey-and go round the village. They also appear at weddings disguised as bears.

Owl-feathers burnt in charcoal are good for fumigating rheumatic limbs; the flesh of the owl is also good for rheumatic patients; so is that of the stork, but you are not allowed to kill it. A tree-frog held in the hand cures excessive perspiration.

To cure consumption you should eat the flesh of a cat and wear its skin on your chest.

Caturact is called "hen-blindness"; to cure it, take a black cock, hold it in a riddle, make it look at the setting sun, and look at the sun yourself; then throw the cock on the ground, jump on the top of a hedge, and imitate the crowing of a cock three times.

On the eve of St. Andrew, girls who wish to get married take a black cat and hold it over the fire; then they throw barley on the fire and say: "Barley, burn; cat, mew; and let my dear one come." To divine which will be married first, girls put bread before a dog and see which piece it eats first.

Clay whistles are made in the shape of cocks, dogs, and pigs.

The souls of the drowned take the form of a horse or dog.

voL. XIl. 
Witches appear as frogs, wild geese, black cats, and crows.

The bear was once a human being; he frightened Christ by his growling, and received his present form. The cuckoo was formerly a girl; she disturbed Christ by crying "cuckoo" and was turned into a bird. The cuckoo becomes a hawk in winter. The swallow was once a girl who was made captive by the Tartars; she prayed to be allowed to return to her country and was changed into a bird.

The stork brings children out of a well (? spring).

A woman was once carried off by a bear and produced two young bear-cubs.

Cocks, owls, and stags' heads made of wood are found on the houses. Eagles, owls, and hawks are killed and nailed to the front of the house.

N. W. Thomas.

\section{Vine-Grafting in Southern France.}

My authority for the following is Madame Gasquet, wife of Monsieur Joachim Gasquet of. Aix-en-Provence, formerly Mademoiselle Marie Girard of Saint-Remy-de-Provence. She is a singularly intelligent woman, and possessed of ' a retentive and accurate memory. She is (I may also mention) a beautiful woman, tall and well formed, and as a girl had a remarkably pure and sweet expression of countenance. In April, I894, Mlle. Girard, as she then was, was aged about nineteen, and was staying with her foster-mother, Liso Confaut, at her mas, or farm, the Mas Pelissier, or Viret. It lies at the eastern end of the northern slope of the Alpilles, a chain of sharp, peaked, rugged, low mountains, running eastward from the Rhône near Tarascon. Formerly they were well wooded, now the upper part is almost all bare rock, but the slopes or foothills grow almonds, olives, and vines, according to the altitude. Mlle. Girard told me of the vine-grafting when I first met her in the autumn of 1894 , but not wishing to trust to my memory only I wrote to her last autumn (1899) for exact details, and in reply she sent me a copy of a letter written by her at the time to her fiance, M. Gasquet, from which I quote the following passages : 